\title{
Climate journalism in a changing media ecosystem: assessing the production of climate change-related news around the world
}

\author{
Schäfer, Mike S ; Painter, James
}

\begin{abstract}
Climate journalism gathers, evaluates, selects, and presents information about climate change, its characteristics, causes, and impacts, as well as ways to mitigate it, and distributes them via technical media to general and specialist audiences. It is an important source of information about climate change for many people. Currently, however, the media ecosystem surrounding climate journalism is changing, with economic conditions becoming more strenuous, more communicators joining the debate, and social media changing the affordances of communication. This advanced review synthesizes scholarship on the status quo and the changes taking place in climate journalism in the Global North and the Global South. While it demonstrates that the scholarship has distinct gaps and biases, it does distill several robust findings. First, it shows that the organizational embedding of climate journalism is changing, with specialist reporters becoming scarce and working under more strenuous conditions and with the emergence of online-born news media and niche sites specializing in climate journalism. It also suggests that few specialist climate journalists exist in the Global South. Second, it demonstrates that the range of roles available to climate journalists has diversified, with a shift from "gatekeeping" to "curating" roles. Third, it indicates that climate journalists' relationships with their sources have changed. Elite sources have been, and still are, important, but their composition has shifted from scientists to a broader range of stakeholders. Correspondingly, there seems to be a strong and rising influence of stakeholder PR on climate journalism.
\end{abstract}

DOI: https://doi.org/10.1002/wcc.675

Posted at the Zurich Open Repository and Archive, University of Zurich ZORA URL: https://doi.org/10.5167/uzh-197137

Journal Article

Accepted Version

Originally published at:

Schäfer, Mike S; Painter, James (2021). Climate journalism in a changing media ecosystem: assessing the production of climate change-related news around the world. Wiley Interdisciplinary Reviews: Climate Change, 12(1):e675.

DOI: https://doi.org/10.1002/wcc.675 


\title{
Climate Journalism in a Changing Media Ecosystem: Assessing the Production of Climate Change-Related News around the World
}

\section{Advanced Review}

\section{First author}

Mike S. Schäfer*, ORCID 0000-0002-0847-7503, University of Zurich, Department of Communication and Media Research, m.schaefer@ikmz.uzh.ch, no conflict of interest

\section{Second author}

James Painter, ORCID 0000-0003-4155-6243, University of Oxford, Reuters Institute for the Study of

Journalism, james.painter@politics.ox.ac.uk, no conflict of interest

\begin{abstract}
Climate journalism gathers, evaluates, selects, and presents information about climate change, its characteristics, causes, and impacts, as well as ways to mitigate it, and distributes them via technical media to general and specialist audiences. It is an important source of information about climate change for many people. Currently, however, the media ecosystem surrounding climate journalism is changing, with economic conditions becoming more strenuous, more communicators joining the debate, and social media changing the affordances of communication. This advanced review synthesizes scholarship on the status quo and the changes taking place in climate journalism in the Global North and the Global South. While it demonstrates that the scholarship has distinct gaps and biases, it does distill several robust findings. First, it shows that the organizational embedding of climate journalism is changing, with specialist reporters becoming scarce and working under more strenuous conditions and with the emergence of online-born news media and niche sites specializing in climate journalism. It also suggests that few specialist climate journalists exist in the Global South. Second, it demonstrates that the range of roles available to climate journalists has diversified, with a shift from "gatekeeping" to "curating" roles. Third, it indicates that climate journalists' relationships with their sources have changed. Elite sources have been, and still are, important, but their composition has shifted from scientists to a broader range of stakeholders. Correspondingly, there seems to be a strong and rising influence of stakeholder PR on climate journalism.
\end{abstract}

\section{Graphical/Visual Abstract and Caption}

\section{CLIMATE JOURNALISM IN A CHANGING MEDIA ECOSYSTEM}

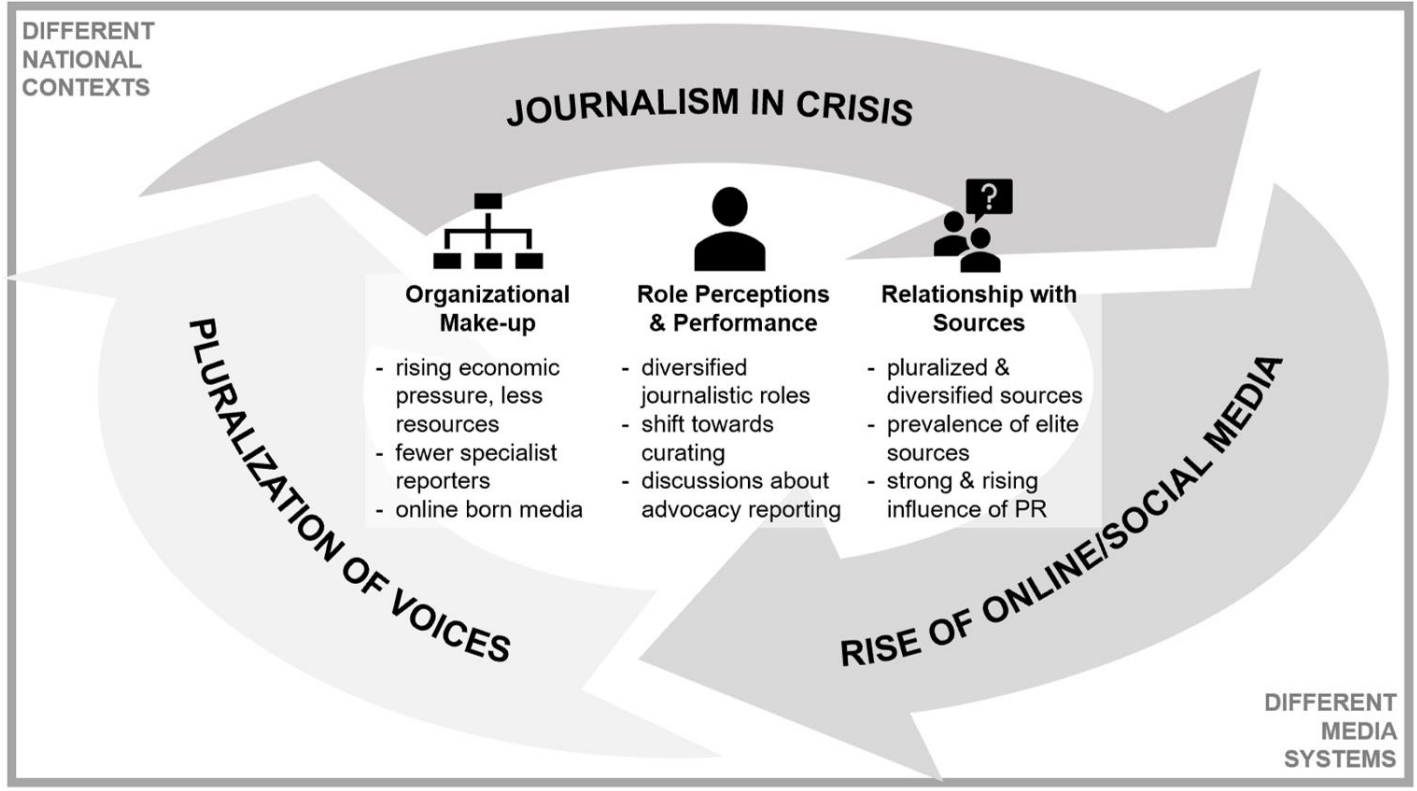




\section{INTRODUCTION}

\subsection{The Continuing Relevance of Climate Journalism}

Climate change is one of the greatest challenges of humanity, but many people find it difficult to engage with and understand (Moser, 2010). As a result, most people's knowledge of climate change comes to a considerable degree from news media. Online survey data from 40 countries, including several in the Global South, shows that in 2020, news media were the most widely used sources of information on climate change (Newman, 2020). 35\% of respondents across countries used television to inform themselves about climate change, $15 \%$ used online sites of major news organizations, $13 \%$ used specialized climate news outlets, and $9 \%$ used alternative sources such as social media and blogs. Scholarship also demonstrates that much of the climate change-related content shared on social media stems from news media (e.g., Pearce et al., 2014) and that the level of trust in mainstream news media in many countries is still higher than trust in other sources (Newman et al., 2019).

In sum, news media are still crucially important for how individuals, organizations and societies understand climate change and how they evaluate and act upon it (e.g., Metag, Füchslin, \& Schäfer, 2017). News media remain "important arenas and important agents in the production, reproduction, and transformation of the meaning" of climate change (Carvalho, 2010, p. 172). Therefore, climate journalism, as the production process behind news media presentations of climate change, has become a crucial object of analysis that is receiving increasing scholarly attention (Brüggemann \& Engesser, 2014; Engesser \& Brüggemann, 2016; Gibson, 2017).

\subsection{Assessing the State of and Changes in Climate Journalism in the Global North and the Global South: Aim of the Article}

This advanced review assesses the status quo of and developments in climate journalism across countries. It examines the organizational conditions under which climate journalism operates, how its actors see themselves and their role, and how they relate to their sources. This has not been done yet (Brüggemann, 2017), although numerous studies have analyzed the production of climate change-related news in various countries including several in the Global South.

We employ a broad understanding of climate journalism that takes recent developments and the emergence of more hybrid forms of (climate) journalism into account. Many definitions of journalism have been proposed, but there is still "little consensus" among scholars on how to define it (Zelizer, 2009, p. 49). This is partly due to the fundamental changes journalism has undergone in recent years (for an overview, see Friedman, 2015), the pluralization of journalistic practices and roles (e.g., Fahy \& Nisbet, 2011), the changes that have taken place in media organizations (e.g., Becker \& Vlad, 2009), and the blurring of boundaries between professional journalists, communication agencies, and "citizen journalists" (e.g., Atton, 2009). Nevertheless, we derived several building blocks for our definition from prior scholarship (for 
an overview, see Zelizer, 2017). We define journalism as a professional practice that gathers, evaluates, selects, and presents news and information, generates original content ${ }^{1}$ guided by journalistic criteria and/or following editorial principles and distributes them via technical media to a (potentially) wide range of general and specialist audiences. Typically, the journalistic occupation and its practice have been embedded in organizational settings, such as traditional media houses and newsrooms. However, this is changing as journalism takes new organizational forms (e.g., Dunwoody, 2014).

Climate journalism is the segment of journalism concerned with climate change, specifically with its characteristics, causes, and impacts in various societal fields, as well as ways of mitigating or adapting to it. This understanding is not tied to a specific journalistic beat or desk - such as the environmental or science desk - but to a topical focus. It includes topics as varied as reporting on the science of climate change, its economic costs, and its impact on the conditions for winter sports. Such reports may be found in the science, business, energy, or sports sections of media outlets. Thus, climate journalism "cuts across beats" (Brüggemann \& Engesser, 2014, p. 400).

This understanding of climate journalism also goes beyond traditional journalism. It includes printed legacy news media and radio and television broadcasts, as well as their online presences and mobile applications (apps). It also includes "digital-born" media organizations that "are not merely digital extensions of newspapers or broadcasters" (Painter, Kristiansen, \& Schäfer, 2018, p. 1), such as Buzzfeed, Vice, and Vox, as well as "niche" sites, such as Carbon Brief and InsideClimate News "which specialise in environment or climate change reporting [...] and have moved from just aggregation or commentary to original reporting" (Painter et al., 2016, p. 11). ${ }^{2}$

\subsection{The Analytical Context: Changes in the Media Ecosystem}

Analyses of climate journalism must consider the changes taking place in the media ecosystem, which encompasses the infrastructural and organizational landscape of journalistic media themselves, the range of communicators surrounding them, and the variety of ways in which they are used. Scheufele (2013) describes the sum of these changes as a "tectonic transformation" (p. 14042), which fundamentally affects journalism and climate journalism. Scholars have identified three major interrelated facets of this transformation (for more detailed overviews, see Dunwoody, 2014; Hansen \& Cox, 2015b; Schäfer, 2017):

First, at least in many countries of the Global North, news media are in crisis as they are finding it increasingly difficult to secure their audiences and, by consequence, their economic basis. The news media industry is an "industry reeling from more than a decade of digital

\footnotetext{
${ }^{1}$ We do not consider social media platforms such as Facebook or Twitter as - even though they also gather, select and present content - they are predominantly content distributors rather than (quasi)journalistic actors. We are aware, however, that the role of social media platforms may change, and that future reviews may have to take these changes into account (cf. Kleis Nielsen and Ganter (2018).

2 We do not include individual or stakeholder communication that does not conform to the definition above, such as citizens' or scientists' blogs or corporate or NGO communications.
} 
disruption" (Newman et al., 2019, p. 10). In "the USA, Canada and Europe, the traditional news business model - i.e. the selling of news in return for advertising and reader subscriptions seems to be in crisis" (Bauer et al., 2013a, p. 4). The audiences reached by many legacy media and the resulting advertising revenue have decreased. The impact of these changes is most notable in commercial media systems, such as that of the US, where the newspaper industry declined by $40 \%$ in the 2000s (Dunwoody, 2014: 29). This has led to many media houses reducing their costs by cutting the salaries of staff and journalists, reducing the frequency of publication, or switching to online-only publication (e.g., Bauer \& Gregory, 2007). This has brought a deterioration in working conditions. Journalists have fewer resources available, yet they have to produce more and more diverse outputs for more channels, including social and mobile media (e.g., Dunwoody, 2014). In response to this situation, new journalistic players have emerged that try to balance editorial independence with sustainable business models (for an overview see Küng, 2016). They include “'digital-born' news media organisations who started off on digital platforms" (Painter et al., 2018, p. 1), such as Buzzfeed, Vice, and Vox, which use the affordances of social and mobile media and try to produce viral content to generate user traffic and, thus, advertisement revenue (Küng, 2016). Other journalistic models rely on philanthropy, crowdfunding, or audience donations, but their success is hard to evaluate at this point (cf. Dunwoody, 2014).

Second, these developments are intertwined with the growing importance of online and social media. Online communication has grown and diversified around the world (Internet World Stats, 2019). Social media "have disrupted established hierarchies of communication, eroding the power of traditional gatekeepers such as large media companies, political parties, and scientific organizations and journals while elevating the potential of individuals to reach large numbers of people as never before" (Pearce et al., 2019, p. 1). Social media facilitate more interactive many-to-many forms of communication that enable more people to participate and user-generated content to be distributed. They also afford users more freedom to select the brands and content they want to follow and blur the distinction between senders and recipients. In these media environments, journalists are not gatekeepers of the news flow. They no longer decide what becomes public and what does not but instead act as "curators" (Fahy \& Nisbet, 2011) of information. Their main roles are to moderate the news flow and provide orientation. Moreover, to an increasing extent, "people find news via digital intermediaries, in particular the dominant search engine Google and the dominant social networking site Facebook," which, in some countries, "are by now more widely used ways of accessing and finding news than the websites and apps of news organizations themselves" (Kleis Nielsen \& Ganter, 2018. p. 1601) - and the news they find there are not journalistically but algorithmically curated (e.g., Nielsen, 2016).

The erosion of traditional news media and the rise of online and social media are generating "growing opportunities for those in politics, government, agencies, businesses and others to bring their messages to the public" (Hansen \& Cox, 2015b: 147), directly circumventing journalist gatekeepers. This has led to the pluralization of voices and content in public communication as "scientists, journalists, advocates, and the people formerly known as audiences" have become "content contributors, each with varying knowledge, background and perspectives" (Fahy \& Nisbet, 2011, p. 782) and many with increasingly professionalized 
communication strategies (e.g., Williams, 2015). This situation has raised concerns about quality control in news media, where fewer journalists have fewer resources available to sift through an increasing amount of professionally produced material produced by outside stakeholders. Debates have emerged regarding the shifting balance of power away from journalism toward public relations (PR) strategies of stakeholders. Potentially, this could lead to a situation where "opinion leaders other than scientists, such as religious leaders, nongovernmental organizations and politicians, [are] successful in formulating their messages about science in a manner that connects with key stakeholders and publics but at times might directly contradict scientific consensus or cut against the interests of organized science" (Bubela et al., 2009: 515).

The scholarship suggests that these three trends are found in many countries but that they are more or less pronounced depending on domestic politics, media systems, and cultural variations. The US, for example, which has been the focus of much academic work on climate journalism (Schäfer and Schlichting, 2014), has weak public service media and a strongly commercialized private sector (Hallin \& Mancini, 2004) that has come under considerable pressure (Newman, 2016). But it also has a large English-speaking audience, which has given rise to major digital-born players like the Huffington Post and climate-specific niche sites such as InsideClimate News, Grist, and the Daily Climate (Brainard, 2015; Painter et al., 2016). Within Western Europe, there are differences in the media landscapes. While "democraticcorporatist" (Hallin \& Mancini, 2004) media systems are dominant in Scandinavia and Germanspeaking countries, the UK has public service broadcasting but also strongly commercialized private media. In "polarized pluralist" (Hallin \& Mancini, 2004) countries such as Italy, Greece, and Spain, broadcasters fare better but newspaper companies struggle to attract readerships (Nicholls, Shabbir, \& Nielsen, 2016; Nicholls et al., 2018).

This cross-country variety is even more pronounced among developing countries and emerging economies. In Africa, the Middle East, Australasia, and Latin America, print circulation dropped between 2011 and 2016, whereas it grew by $40 \%$ in Asia. The rise of print media was particularly pronounced in India and China (WAN-IFRA, 2017). The media landscape in China has changed rapidly in recent years with the arrival of several important commercial players, particularly in the fields of print, online, and social media, accompanied by the continuously strong presence of the state television channel, CCTV, and other governmentowned news media. In India, by contrast, state-owned media are marginal, but the number of privately owned TV news channels has increased significantly from around 30 in 2006 to more than 100 in 2017. This is in addition to the more than 90,000 print media titles currently available (Chadha, 2017). At the same time, many Indians access news via online media, especially search engines social media and messaging services (Aneez et al., 2019). In South America, while Brazil has historically been a television nation (Carvalho \& Loose, 2018), survey research shows that social media overtook TV news as the most widely used source of climate change-related news in 2020 (Newman, 2020). Similar patterns have been found in Argentina and Chile. In Mexico, television and radio, while less favored than online and social media, remain crucial for millions of people who are not online. These trends and their national and regional variations must be considered when analyzing climate journalism. 


\section{POSITIONING THE REVIEW WITHIN THE RESEARCH FIELD}

Analyses of climate change communication emerged in the 1990s, in the wake of a "considerable expansion of research interest in media and communication processes regarding the environment" (Hansen \& Cox, 2015a, p. 1). This growth is visible in both meta-analyses of the scholarship (Comfort and Park, 2018; Pearce et al., 2019; Schäfer and Schlichting, 2014) and the proliferation of encyclopedias covering the field (Hansen \& Cox, 2015b; Holmes \& Richardson, 2020; Leal Filho et al., 2018; Nisbet et al., 2017).

However, the scholarship on climate change communication has imbalances and gaps, both in general and with regard to climate journalism. First, most of the publications come from, and focus on, countries from the Global North, particularly the Anglosphere. In the field of environmental communication, one study found that $52.8 \%$ of all publications examined the US, while only $6.4 \%$ analyzed China, "major developing countries like Brazil and India appeared in less than two percent of studies," and almost no studies focused on "poorer nations such as Ghana or Bangladesh" (Comfort \& Park, 2018 p. 869). In scholarship on climate change communication, the US and UK have received the most attention, jointly accounting for more than a third (35.5\%) of all studies published in the Web of Science and other outlets (Schäfer \& Schlichting, 2014). In contrast, communication in emerging economies and developing countries - many of which are among the most vulnerable to climate change - is generally under-researched (Comfort \& Park, 2018; Nguyen, Tran, \& Da, 2020; Schäfer, 2012b; Schäfer \& Schlichting, 2014), albeit with exceptions. For instance, a considerable number of studies have been published on India (Billett, 2010; Keller et al., 2019; Painter, 2011, 2013). In this review, we deliberately take a broader perspective, searching for studies on both the Global North and the Global South to obtain a global picture. Second, most studies focus on traditional news outlets, namely legacy print media or their online presences, and the journalistic content they produce. In scholarship on environmental communication, studies analyzing print media accounted for most of the published research until 2017. In fact, their proportion even increased (Comfort \& Park, 2018), which is likely due to the availability of full-text print databases such as LexisNexis and Factiva facilitating comprehensive analyses. In studies of climate change communication, print media accounted for more than two-thirds of all studies until 2010 (Schäfer \& Schlichting, 2014). This focus on print media is disproportionate to their importance as sources of climate change-related information; in 2020, printed newspapers were only used by $5 \%$ of international survey respondents and were even less important as a source than conversations with friends and family (Newman, 2020). In contrast, broadcast and online journalism, which have a much wider audience, are analyzed considerably less often. Even as scholarly attention to online communication about climate change increases (Schäfer, 2012a), most studies focus largely on Twitter (Pearce et al., 2019). Overall, "scholars are still struggling to catch up to the rapid changes to our media system" (Nisbet \& Newman, 2015, p. 334). This review aims to remedy this by adopting a broader understanding of climate journalism and considering more recent developments, such as online-born and niche journalistic media.

Third, our broad perspective reveals that scholars have not granted all aspects of climate journalism equal attention. Although some scholarship exists on the sources of climate 
journalists (e.g., Takahashi, 2011), their self-perceptions and attitudes (e.g., Brüggemann \& Engesser, 2014), and their working routines (e.g., Lück, Wozniak, \& Wessler, 2016), significantly more scholarship focuses on the output of journalism, that is, climate change coverage (for an overview, see Painter \& Schäfer, 2018). In contrast, this advanced review focuses specifically on the production of climate journalism, that is, on the structural settings in which journalistic content is produced and the procedures involved in its production.

Our focus is on published and mostly, but not exclusively, peer-reviewed scholarship. This corpus of research was compiled by first searching the Web of Science, Scopus, and Google Scholar databases (similar to, e.g., Comfort \& Park, 2018; Schäfer \& Schlichting, 2014). Second, we systematically searched relevant journals, such as Environmental Communication for publications relevant for our review (similar to Guenther \& Joubert, 2017). Third, to find publications on climate journalism in the Global South in particular, we asked colleagues with area-specific expertise for recommendations. Fourth, we searched the scholarly literature referenced in all of the identified studies to find additional relevant material.

\section{THE CHANGING ORGANIZATIONAL MAKE-UP OF CLIMATE JOURNALISM}

Generally, the production of news - including climate change-related news - has been analyzed along three major dimensions (Hansen, 2010; Shoemaker \& Reese, 2013): the organizational settings of media houses and newsrooms in which (climate) journalism is embedded (Gibson, 2017), the role perceptions and role performance of climate journalists (Brüggemann, 2017), and climate journalists' relationships with their sources (Anderson, 2017). The review is structured according to these three dimensions, beginning with the changes in organizational settings.

Climate journalism, like all journalism, is influenced by its organizational contexts and structures. The available resources - in terms of time, finance, and personnel - and the organization of newsrooms, including their specific working routines and procedures, have a considerable impact on (climate) journalism, the work of its protagonists, and its outcomes (Shoemaker \& Reese, 2013).

Accordingly, scholars have analyzed the organizational make-up of (climate) journalism and its development. Most of this research has not analyzed climate journalism as such but rather science or environmental journalism, mostly in legacy media organizations or as a profession in general (for overviews, see Dunwoody, 2014; Friedman, 2015). Methodologically, these studies almost exclusively rely on qualitative or quantitative interviews of journalists, and most focus on specific national cases. While most of these studies focus on countries from the Global North, especially those published in international peer-reviewed journals, a considerable number of such analyses also exists on countries from the Global South. Overall, scholarly evidence on the organizational structure of climate journalism is solid regarding some aspects but still weak regarding others. The main findings of the research are summarized below.

\subsection{The changing organizational characteristics of climate journalism}


The organizational characteristics of climate journalism are changing rapidly and considerably. This is particularly true in the US, where studies have revealed a decline in science and environmental reporting due to the growing pressure on the traditional business models of legacy media. This has led to the restructuring and downsizing of newsrooms, fewer beats, fewer specialist journalists, generalist rather than specialist reporters covering science and the environment, outsourcing to freelancers, the migration of specialist reporters to general assignments or other desks, less time for investigative reporting, and a need to produce more output for a greater variety of platforms (Boykoff \& Yulsman, 2013; Friedman, 2015; Gibson, 2017). Similar developments have been identified in Canada (Callison \& Tindall, 2017), although their extent is less clear due to a smaller number of available studies.

These problematic trends are less pronounced, however, in countries with strong public service broadcasting, many of which are European countries. While legacy media business models in these countries are under threat, they have not come under as much pressure as those in the US and Canada. In the UK, the last comprehensive survey of science and environmental reporters was conducted before many of the changes described above took significant effect. It found that, unlike the US, the UK experienced an unprecedented increase in science, health, and environment journalists between 1989 and 2005, mostly driven by rising staff numbers at the BBC (Williams \& Clifford, 2010). However, the picture since 2005 has not been mapped in detail. While some studies have reported a reduction in specialist and climate journalism (e.g., Boykoff \& Yulsman, 2013), the BBC has maintained a large team of science and environmental reporters, and the Guardian has strongly increased its team of environmental journalists (Painter, 2013). In addition, the BBC appointed a chief environment correspondent and Sky News its first climate correspondent ever in 2019. In Switzerland, the number of science reporters has decreased, but less so than in the US, with many Swiss specialist journalists remaining in public service broadcasting (Kristiansen, Schäfer, \& Lorencez, 2016). Lester (2013) demonstrates that the number of environmental journalists in Australia increased during periods of public interest and decreased during troughs. However, detailed studies of these developments are lacking.

However, even studies on environmental communication in the Global North have rarely gone beyond a broad analysis of science and environmental journalists to focus specifically on climate journalists. Accordingly, there are strong variations in how much is known about the specific organizational status of climate journalists, the division of labor between them and general reporters, or the impact of the structural changes outlined above on climate reporting in recent years. Furthermore, the small number of existing studies on climate journalism have focused on specific organizational aspects. A Danish study shows that "climate change has traditionally been part of the environmental beat[,] covered by rather specialized journalists, in some cases even by the same journalists, for decades" (Eskjær, 2017). In Germany, climate journalists work across beats. A standardized survey of 85 climate journalists working for print media there found that most of them wrote for science desks (66\%) but that many also wrote for political (64\%), economics (41\%) and "miscellaneous" (41\%) desks (Peters \& Heinrichs, 2005: 95). A Portuguese study reports "a serious shortness of human resources and time pressure on [climate] journalists" due to "drops in print circulation, the transfer of readers to digital platforms, and the severe economic crisis," all of which have meant that "newsrooms 
have gravely shrunk and are mostly composed of young temporary hires with the pressure to produce more and faster for less and less pay" (Horta \& Carvalho, 2017).

\subsection{The organizational conditions of climate journalists in the Global South}

Although the evidence on the organizational conditions of climate journalists in the Global South is not as robust, research suggests that climate journalists in the Global South operate in different organizational conditions, and that those have developed differently as well. Scholarship on Latin America shows that there are very few specialist climate journalists in mainstream media organizations. For example, Peru has no environmental beat or associations (Takahashi \& Martinez, 2017), and Argentina has been described as having "practically no journalists who are climate specialists" (Mercado-Sáez \& Galarza, 2017). Brazil, however, appears to be an exception: In the 2000s, the country exhibited strong science and environmental reporting, with major titles such as Folha de Sao Paulo boasting an experienced science team, TV Globo regularly covering climate change, and specialist business papers such as Valor Economico employing environmental correspondents (Fioravanti \& Painter in Painter, 2011). However, economic pressures in 2019 caused legacy media organizations to lay off many journalists, including 40 journalists from TV Globo (which may have affected their climate coverage), two science reporters at $O$ Estado de Sao Paulo and one from Folha de Sao Paulo.

As mentioned above, major changes are taking place in the Indian media landscape, particularly in the use of mobile phones to access news online (Nielsen \& Sen, 2016). However, scholarship on how these changes are affecting climate journalism is scarce. The available evidence suggests that climate change is covered by specialist beats in many legacy media outlets. The Times of India, the largest English-language newspaper by circulation in the world, had a dedicated climate reporter for several years (Jogesh \& Painter in Painter, 2013), and the Hindustan Times and the Indian Express had specialist environmental reporters in the early 2010s (Mittal, 2012). Interviews with Indian media scholars suggest that in 2019, many legacy media organizations, such as the Times of India, the Hindu, the Indian Express, the Hindustan Times, Mint, the Economic Times, and the Business Standard, had at least one dedicated environmental or climate reporter, many of whom were based in Delhi and covered the policy angle (Author interviews, 2019). Climate change is mostly covered in India during the annual meetings of the United Nations Framework Convention on Climate Change (UNFCCC)- in which the country often plays a major role (Schäfer, Ivanova, \& Schmidt, 2014; Schmidt, Ivanova, \& Schäfer, 2013) - and by political rather than environmental correspondents (Painter, 2019). In addition, scholars have shown that entertainment is granted priority in many media houses as they are commercial enterprises (Chadha, 2017) and that editorial emphasis on Bollywood celebrities, sports, and business may have suppressed climate coverage and reduced the number of specialist climate journalists (Painter, 2019).

Regarding China, little scholarship is available on the organizational context of climate journalists. Generally, scholars have described a rapidly changing media environment in the country since the 1990s, when the number of media outlets increased substantially. This period saw the emergence of commercial media organizations that began to explore a broader range of issues and viewpoints, including environmental ones, while also operating within an 
authoritarian political system (Burgh \& Zeng, 2012; Geall \& Hilton, 2013; Yang, 2010). Qualitative interviews with environmental correspondents from commercial media outlets, such as Southern Youth Daily and Caijing, and state organs, such as the Xinhua News Agency and China Youth Daily, suggest that the dominant organizational context was not characterized by a collapsing business model but rather by a rising governmental emphasis on, and acceptance of coverage of, environmental issues (Burgh \& Zeng, 2012). Accordingly, environmental journalists appear to have had increased influence on governmental decisions (Burgh \& Zeng, 2012). This is in line with the observation that many ecological campaigners in China worked as journalists first (Geall, 2013). Similarly, environmental issues have become more relevant online, particularly on popular websites, portals, messaging services and microblogging platforms such as Sina Weibo (Rauchfleisch \& Schäfer, 2015; Tandoc \& Eng, 2017). However, more analysis is needed on the specific situation of climate journalists among Chinese environmental journalists, especially in light of research showing an increase in Chinese media coverage of climate change and the spread of the issue to a plurality of news desks (Li \& Dan, 2017).

Significantly less is known about climate journalism in Africa, a continent that has been described as the "least responsible, most affected, and least informed" when it comes to climate change (BBC World Service Trust, 2009, p. 1). The few existing studies of climate change communication in Africa have almost exclusively focused on the volume and content of news media coverage (e.g., Nassanga et al., 2017) and demonstrate a bias toward print media and the countries of South Africa and Nigeria (Antwi, 2018; Schmidt et al., 2013; Tagbo, 2010). The rare studies of journalists who cover climate change suggest a lack of scientific understanding, resources and experienced reporters in newsrooms and argue that they are illequipped to deal with climate change (Finlay, 2012). A study from Ghana shows that general reporters and not specialists cover science topics (Appiah et al., 2015).

\subsection{New organizational forms of climate journalism}

The scholarship has also emphasized that new organizational contexts for climate journalism have emerged. These are mainly digital-born players that have established themselves as general news providers in several countries in and beyond the English-speaking world. Their target audiences are under 35, and in some markets, they have managed to rival legacy media outlets (Painter, 2016). Examples include international brands such as the Huffington Post and BuzzFeed, both of which have presences in several languages and countries. Many of these outlets, including the Huffington Post, BuzzFeed, Vice, Vox, and Quartz, focus specifically on environmental issues such as climate change and often have feature sections or indexes on these topics, partly because such issues are of interest to their young target audience (Painter et al., 2018). Online-surveys suggest that online-born players have larger audience shares than legacy media in countries where consumers are particularly interested in environmental news (Fletcher in Painter et al., 2016). In the UK in 2016, the Huffington Post was used by $19 \%$ of consumers interested in environmental issues, which is comparable to the figures for the Guardian (18\%). In the US, the Huffington Post was used by $36 \%$ of news users, making it the most popular online news medium for this audience group (Fletcher in Painter et al., 2016). Generally, it has been shown that the online-born media base their editorial decisions on audience metrics and algorithms to a much greater extent than most legacy media outlets do 
(Küng, 2016). However, they differ somewhat in how they distribute climate-related content. The Huffington Post relies heavily on blogs, while Vice relies on "personal narration" videos; BuzzFeed depends on a mix of listicles, quizzes, photo galleries, and irreverent content, and Vox focuses on "explainers." These differences provide some background information about the "how" and "why" of climate change (Painter et al., 2016).Funding models and editorial priorities also vary across countries. Online-born players in France, Germany, Spain, and the UK have been shown to be editorially distinct: some seek to offer stand-out, in-depth journalism and investigative reporting on a few issues, while others covered a broad range of topics (Nicholls et al., 2016). International online-born players, in particular, can struggle with the tension between local and global content (Nicholls et al., 2018). India also has a wide range of digital start-ups that follow different journalistic models, most of which are contentbased, aggregation-based or non-profit entities (Nielsen \& Sen, 2016). Some new players, such as IndiaSpend, Scroll, The Wire, Gaon Connection, the Caravan and the News Minute, include extensive coverage of climate change within their general news offerings. In Brazil, Nexo, a digital start-up founded in 2015, is one of several online-born players to include climate news in its content. Overall, however, little is known about the organizational aspects of climate journalism, such as the presence of specialist climate beats, the employment status and working conditions of journalists, or the organization of the newsroom, among these new players.

Several environmental correspondents who had formerly worked for legacy media now work for digital-born news players (Painter et al., 2016) and niche sites covering climate issues (Brüggemann, 2017; Gibson, 2017). The proliferation of such sites, particularly in the US and the UK over the past 15 years, has been noted by scholars (e.g., Boykoff \& Yulsman, 2013; Brainard, 2015). Some, such as Carbon Brief and InsideClimate News, offer highly specialized, in-depth, high-quality coverage on the scientific and socio-political aspects of climate change, along with additional services such as an aggregated news service. Others, such as Grist and Climate Progress are more advocacy-oriented (Brainard, 2015; Fahy, 2017). Some outlets, such as the Daily Climate, have moved from mere aggregation or commentary to original reporting, and some offer environmental stories as part of a specialist (partly investigative) approach (e.g., the Center for Investigative Reporting, ProPublica), while others, including Climate Central, are hybrid journalistic-scientific enterprises (Brüggemann, 2017).

Niche sites are not restricted to the US and the UK. China Dialogue is a leading specialist site covering environmental issues with a strong focus on climate change. It targets both Chineseand English-speaking audiences. Its sister site is India Climate Dialogue, which was set up in 2018 as a dedicated outlet for impartial and objective news on all aspects of climate change. Carbon Copy also focuses on energy issues in India but covers several aspects other than climate change. In Brazil, Observatório do Clima (Climate Observatory), a network founded in 2001, brings together several civil society organizations to offer climate news in English and Portuguese. One aspect common to all of these sites is that former journalists from legacy media occupy senior managerial or editorial positions. However, little scholarship has analyzed the nature of the climate journalism offered by these sites, including the degree to which they pursue an editorial line independent of government, NGOs, or other interest groups. 
Some have argued that niche sites generally only reach small audiences who are already wellinformed about climate change, resulting in echo-chambers of like-minded publics (Gibson, 2017). However, a recent survey of 40 countries suggests that specialist outlets covering climate issues rank third for general audiences as a source of climate news after television and online sites of major news organizations (Newman, 2020). Given the variety of these sites, the novel formats they use to present climate information, and their apparent popularity with mainstream journalists and policy-makers, more in-depth research on their organizational practices, professional backgrounds, and editorial approaches is needed. This is also true for other emergent online formats, such as climate-related fact-checking sites, data-based network initiatives (Russell, 2016), start-up news companies acting as intermediaries between legacy media organizations and freelance reporters (Hellmueller, Cheema, \& Zhang, 2017), and intermediary organizations, such as Science Media Centre (Wihbey \& Ward, 2016).

\section{CLIMATE JOURNALISTS' PROFESSIONAL ROLES AND ROLE PERCEPTIONS}

How journalists work - how they select their topics, conduct their research, interact with sources, and present content - is not only influenced by their organizational embedding but also by how they perceive their role and how they act upon these professional selfperceptions (Shoemaker \& Reese, 2013). Journalists may perceive themselves as "neutral" mediators of the news flow, watchdogs who critically evaluate societal elites, or advocates of a cause, and these perceptions influence their work (Brüggemann, 2017).

For many years, journalism scholars have analyzed journalistic role conceptions, both generally (e.g., Hanitzsch, 2011) and with regard to environmental (Friedman, 2015), science (Schäfer, 2011), and climate journalists (Brüggemann \& Engesser, 2014). These scholars have focused both on journalists' self-perceived roles and their actual role performance or enactment (Mellado, Hellmueller, \& Donsbach, 2017; Tandoc \& Takahashi, 2014).

This research is also mostly based on qualitative interviews with or surveys of journalists and has thus focused on journalists' self-assessments (Tandoc and Takahashi, 2014). There have been calls for ethnographic research or participant observation studies in newsrooms, which might more closely explore the complex interaction between the macro, meso, and micro levels but such calls have rarely been answered (Hansen \& Cox, 2015a; O'Neill \& Smith, 2014). Most of the available scholarship has focused on journalists from the US or the UK (e.g., Murcott \& Williams, 2013; Sachsman, Simon, \& Valenti, 2010) or other countries in the Global North. Much less is known about the Global South (for an overview, see Shanahan, 2009). Nonetheless, several findings can be extracted from this scholarship.

\subsection{The diversification of roles and role perceptions}

There is broad agreement among scholars that the range of roles available to journalists and their role perceptions have diversified since the early 2000s (Brüggemann, 2017) due to changes in the media ecosystem surrounding them. Fahy and Nisbet (2011) conducted qualitative interviews with journalists and typologized how journalistic roles had developed from traditional "agenda-setter" or "watchdog" roles to "curators" of science information, 
"conveners" of experts and interested parties, "public intellectuals" synthesizing and presenting information from a specific perspective, and "civic educators" (p. 778)

\subsection{From "gatekeeping" to "curating"}

Fahy and Nisbet's typology proved influential, and subsequent research has shown that the actual roles played by many climate journalists' are no longer gatekeeping roles involving responsibility for the selection of topics, information, and voices for public dissemination. Many climate journalists have assumed curator roles, whereby they find relevant content, restructure it, and presenting it with added evaluation and orientation to particular audiences (Fahy \& Nisbet, 2011). They have become "pathfinders" and "scouts" (Brüggemann, 2017) of the news flow or "cartographers" pointing out interesting news (Santamaria cited in Trench, 2009), marking a notable deviation from the traditional gatekeeper functions that involved the top-down provision of content to the public.

However, it should be noted that traditional gatekeeping roles appear to be still prevalent among some climate journalists. Science journalists have been shown to demonstrate a continued prevalence of rather uncritical "neutral informer" and "translator" roles (Dunwoody, 2014), particularly in the Global South. An international survey of 592 science journalists from all continents found that $43 \%$ believed that their role was "to inform", $23 \%$ "to translate complex material", and $13 \%$ "to educate"; less than $10 \%$ saw thought their role entailed "mobilising or entertaining the public" or being a "public watchdog" (Bauer et al., 2013b, p. 24). The rare items of scholarship on science journalists in the Global South have generally demonstrated a "scarcity of critical science reporting" (Nguyen et al., 2020, p. 980). Similarly, a survey of more than 60 climate journalists from India, Germany, Switzerland, the US, and the UK identified the presence of a common transnational "interpretive community" in support of the mainstream consensus on anthropogenic climate change and had more traditional self-perceptions as explainers of a complex phenomenon (Brüggemann \& Engesser, 2014), although no similarities or differences between the countries were discussed. ${ }^{3}$

\subsection{Advocacy roles seem to gain more prominence}

In addition to these changes, there have been recent discussions regarding more pronounced advocacy roles, which may be specific to environmental and climate journalism. Although the dichotomy between "advocacy" and "neutral" is problematic, advocacy journalism "presents news from a distinct point of view, does not separate facts from values, and is motivated often by a political or social agenda" (Fahy, 2018, p. 856). Among environmental reporters, some studies indicate that such positions may gain momentum. Lester (2013) found that environmental journalists in Australia were often perceived by colleagues and editors as advocates. Classifying environmental journalists in Greece as "scientifically objective, environmentally responsible journalists," "environmental crusaders," or "objective-pure journalists," Giannoulis, Botetzagias, and Skanavis (2010) concluded that 26\% were

\footnotetext{
${ }^{3}$ Lück et al. (2016) carried out semi-structured interviews with 36 journalists from nine countries (including South Africa, Brazil, India, Mexico, Qatar, and Poland) at three COP conferences and concluded that professional boundaries between journalists and NGOs were temporarily blurred there due to a "camp feeling" which was conducive to processes of co-production and a common interpretation of what was happening. However, the authors also stressed the exceptional status of COP conferences.
} 
"crusaders" who believed they "should lead their readers in assuming responsibility for a better environment" (p. 445 ). Sachsman et al. (2010) found that more than one in three environmental journalists in the US believed they should, at times, advocate for the environment. However, Tandoc and Takahashi (2014) found that among the 103 US environmental journalists they surveyed, the role of advocate was the least prominent, and Gibson et al. (2016) were told by all ten US journalists they interviewed that they did not see themselves as advocates.

However, research also suggests that advocacy roles are more pronounced among online journalists. In the US, "those working for online-based organisations saw a consistency between individual and organisational advocate roles" (Tandoc \& Takahashi, 2014, p. 903), and several digital-born or online-based niche media covering climate issues tend toward advocacy journalism (see above).

In addition, there have been recent examples of legacy media adopting advocacy positions on climate change. For example, the Guardian's "Keep it in the Ground" campaign (www.theguardian.com/environment/series/keep-it-in-the-ground) was aimed at pressuring the Wellcome Trust and the Gates Foundation to stop investing in fossil fuel companies. The campaign revealed divisions among the newspaper's environmental journalists with regard to their role conceptions (Forde, 2017; Painter, 2019; Salvesen, 2018). The campaign also helped to move climate change out of the environmental "ghetto" into other areas of the Guardian's operation, at least temporarily, thereby enriching its coverage of the issue (Salvesen, 2018).

The Guardian appears to be an outlier in terms of its adoption of a specific climate campaign, but other prominent media outlets have followed its example of favoring the terms "climate emergency" or "climate crisis" over "climate change," which might be interpreted as a form of communication advocacy. These include Der Spiegel in Germany, Gazeta Wyborcza in Poland, the Canadian Broadcasting Corporation (CBC), the Spanish news agency EFE, and Noticias Telemundo, the leading Spanish-language news provider in the United States. Moreover, around 400 media organizations around the world joined the "Covering Climate Now" initiative (www.coveringclimatenow.org) launched in April 2019 to produce more and better climate coverage, prompting warnings that it could become an echo chamber for activism (Nisbet, 2019).

\subsection{Newsroom characteristics and shifts in climate journalists' roles and role perceptions}

The scholarship also shows that shifts in the role perceptions and role performances of climate journalists are tied to the specific resources and opportunity structures of the newsrooms in which they work. As working conditions for climate journalists worsen, time and resource restrictions often limit the options to watchdog or investigative climate journalism. However, the degree to which this is happening in media organizations or outsourced specialist outlets is unclear. Too little is known about the other influential factors, such as the imperative to be entertaining, which is particularly strong in India and the US (Tandoc \& Takahashi, 2014), affecting the role perceptions and practices of climate journalists.

Similarly, the role of technological changes on the role perceptions of climate journalists has yet to be analyzed. It is likely that the instant metrics of audience reach and engagement that are available to many environment journalists affect their work. The growing primacy of visual 
story-telling in legacy (Painter \& Osaka, 2019) and online media (Le.ón \& Erviti, 2016) and changes in editorial priorities and practices may also impact role perceptions and performances.

\section{CLIMATE JOURNALISTS' RELATIONSHIPS WITH THEIR SOURCES}

As journalists cannot attend all events they wish to cover - and as their resources to engage in such on-site research have declined in many countries (Dunwoody, 2014; Schäfer, 2017) - they have to rely on "sources." These are individuals or organizations who provide information or content, ranging from background information to verbatim quotes to visual or audiovisual material (Williams, 2015). They include scientists, politicians, NGOs, and business representatives, as well as wire services and news agencies (Comfort, Tandoc, \& Gruszczynsk, 2019). These sources are important. They can give or withhold information from journalists, try to influence their views and the focus and framing of their coverage, and eventually "have a significant impact on media content because they are the origin for much of what journalists know" (Shoemaker \& Reese, 2013, p. 108).

There is "a long tradition of examining source influence on journalistic decisions" (Anderson, 2017 , p. 469). Both generally and specifically in relation to climate journalism, these studies often rely on indirect measures of source interaction and selection. There are few ethnographic studies of newsrooms that involve direct observation of (climate) journalists interactions with sources (cf. Anderson, 2015). Most findings are based on journalist surveys (e.g., Brüggemann \& Engesser, 2017), interview, document-based analyses of strategic communication with sources (e.g., Carpenter, 2001), or extrapolations from media content analyses (e.g., Eide \& Kunelius, 2010).

These studies are biased in several ways. They mostly analyze the Global North, particularly Anglophone countries, and have focused on some sources - such as the Intergovernmental Panel on Climate Change (IPCC), environmental NGOs, or climate change skeptics - far more than others, such as businesses or politicians (for an overview, see Anderson, 2017). Nonetheless, they have produced a solid body of evidence from which several findings can be derived.

\subsection{The influence of personal, organizational, and sociocultural factors on source selection}

Research has demonstrated that source selection is a complex process involving interrelated personal, organizational, and larger sociocultural factors (for overviews, see Brüggemann \& Engesser, 2017; Gibson, 2017). "News entry for both official and non-dominant sources", for example, "is dependent on numerous contingencies (internal and external to the media)." These include "financial and personnel advantages enjoyed by official sources" and sources' response times to journalists' requests (Anderson, 2015, p. 178; 2017, p. 470f.). In addition, established journalistic norms and news values have also been impactful (for an overview, see Boykoff, 2011): 
The notion that news articles should be 'factual', 'neutral' and 'balanced' is a powerful norm that guides working practices. Adherence to the balance norm (the notion that impartial reporting must give approximately equal space to both sides of the story) has had particularly serious consequences for the quality of reporting of climate change (Anderson, 2017, p. 476)

This is due to an overly strong representation of voices skeptical of climate science (Boykoff \& Boykoff, 2004; Engesser, 2017). Other norms, such as an orientation toward authorities, or news values, such as novelty and personalization, have also been influential (Boykoff \& Boykoff, 2007).

\subsection{Climate journalists' sources have pluralized and diversified}

Research has shown that an increasingly diverse range of sources is available to climate journalists. There is "a cacophony of voices vying to make themselves heard" on the issue of climate change (Anderson, 2015, p. 178), from politicians, corporations, and NGOs to celebrities and social media influencers.

In addition, many of these sources have professionalized their communication efforts in recent years.

Journalism's contraction in the past two decades has been more than matched by an expansion in the field of PR [in which] those in the energy, chemicals, agriculture, pesticide, and biotechnology industries [have] expanded their public relations efforts, but so have public and civil society players such as universities, research councils, specialist science publications, charities, NGOs, and other activists (Hansen, 2010, p. 198).

By now,

sources have developed an entire industry to tightly control the flow of information; PR operatives try to influence news agendas and coverage with pre-packaged materials such as press releases, news briefings, press conferences, persuasive personal communications, and sometimes manipulative and hidden media management tactics (Williams, 2015, p. 197).

\subsection{Elite sources}

The scholarship has shown that elite sources are important for journalism in general and in many countries. Journalists "have long been criticized for being dependent on establishment sources, privileging the voice of the elite at the expense of marginalized voices" (Comfort et al., 2019, p. 4; cf. Olausson, 2009).

This is also true for environmental and climate journalism. Environmental journalists have been described as "notoriously authority oriented" and studies "have virtually without exception shown that the sources who get to be quoted [and] define environmental issues [are] predominantly those of the public authorities, government representatives, industry and 
business, and independent scientists" (Hansen, 2010 p. 56). A study of climate change coverage in 19 countries demonstrated that politicians made up approximately $50 \%$ of all (print) media sources in the late 2000s, with civil society representatives, such as NGOs, accounting for $28 \%$ and scientists for $14 \%$ (Eide \& Kunelius, 2010). Similarly, a study of print articles published in China, India, Singapore, and Thailand between 1995 and 2017 showed that journalists in all four countries relied heavily on government sources. Such sources featured in roughly $25-50 \%$ of the 3,781 articles, depending on the country (Comfort et al., 2019), followed by scientists, activists, business interests, and, finally, members of the public.

Scholars have long hoped that online media, with its lower thresholds for participation and reduced focus on professional gatekeepers, would remedy this one-sided source structure (Schäfer, 2012a). However, this has not proved to be the case (Gibson, 2017). Online news has been found to be

very similar to the news of other media in being heavily reliant on state representatives (such as government ministers, judges and public officials) and on experts. Together, these represent 70 per cent of the sources of online news compared with 64 per cent of press sources and 60 per cent of television sources. On average, online news actually gives less of a hearing to the political opposition, civil society and individual citizen sources than either television or newspaper news (Anderson, 2015, p. 179; cf. McNutt, 2008; Takahashi \& Tandoc, 2016).

Across all media, individual citizens still have only a marginal presence as news sources. The most visible sources in the news remain organizations who produce information professionally and often communicate it strategically (Comfort et al., 2019).

However, studies have also shown that the range of elite sources has diversified in recent years. "There is evidence that suggests scientists serve to define the issue in the public sphere as it first emerges, but that journalists increasingly turn to official sources as the issue becomes politicized" (Comfort et al., 2019). When climate change

first began to gather news media attention in the early to mid-1980s, scientists were the principal news sources[.] However, from the late 1980s politicians increasingly influenced the agenda and it moved from being a story largely confined to specialist science sections to a more general news item focusing on political controversy [in which] journalists increasingly relied on political sources (Anderson, 2017, p. 469).

In specific situations, such as the International Conferences of the Parties (COPs) to the United Nations Framework Convention on Climate Change, sources such as NGOs are more important as they can provide timely information and interpretation in a complex communicative setting and engage in content coproduction with journalists (Lück et al., 2016). Overall, however, studies have demonstrated that even "better-resourced NGOs and grassroots activists alike have often had trouble gaining coverage" and that "their influence does not routinely extend to commanding a 'prominent role' in continued debates" (Williams, 2015, p. 200).

\subsection{The persistent media presence of climate-skeptic sources}


Research indicates that climate skeptics still feature in environmental news stories in some countries. Partly due to the journalistic norm of balanced reporting (Boykoff, 2011; Boykoff \& Boykoff, 2004; for an overview, see also Brüggemann \& Engesser, 2017) and the efforts of the "climate denial machine" - which consists of powerful sponsors and vocal front groups (Dryzek, Norgaard, \& Schlosberg, 2011; Schlichting, 2013) - skeptics have historically made up a notable portion of news sources, particularly in Anglosphere countries, such as Australia, the US, and the UK (Bacon \& Nash, 2012; Painter, 2011; Painter \& Ashe, 2012). Between 1988 and 2002, about half of all US press and TV accounts of climate change featured skeptic sources (Boykoff \& Boykoff, 2004). In the mid-2000s, such sources featured in about a third of all US news articles (Boykoff \& Boykoff, 2007) and a fifth of British articles on climate change (Painter \& Gavin, 2016). More recent research on major television and newspaper outlets in the US from 1988 to 2017 shows that climate change counter-movements (i.e. skeptical organizations such as the Heartland Institute and the Heritage Foundation) continued to have a strong presence (Boykoff \& Farrell, 2019) and gained even more media visibility after the election of the Trump administration. Their presence in 2017 was twice that of the annual average coverage for the previous decade.

In contrast, various studies have shown that climate skeptics are largely absent from the media in other countries of the Global North and the Global South. For example, a study of 10 countries' coverage of the IPCC AR5 report of 2013-14 showed that the UK had a higher presence of skeptical voices than Japan, France, South Africa, Bangladesh, and Brazil (Painter, 2017). Regarding Brazil, several studies have demonstrated notably high levels of public concern about climate change and an absence of climate skepticism in the Brazilian media (e.g., Dayrell \& Urry, 2015). However, none of these studies covered the time since President Bolsanaro, a climate skeptic, assumed office in January 2019. In general, not enough is known about the (possible) presence of climate-skeptic groups and their influence on journalists in countries outside the Anglosphere.

Importantly, a five-country study (which included Germany, India, the UK, the US, and Switzerland) showed that many climate journalists do not consider skeptics to be trustworthy sources (Brüggemann \& Engesser, 2014) and that they often contextualize skeptics critically. Brüggemann and Engesser (2017) demonstrated that "while the IPCC is mentioned or quoted in a neutral tone ( $57 \%$ of articles in which it is mentioned or quoted), more than $69 \%$ of the articles that mention or quote contrarians also contextualize them in a negative way" (p. 62). Moreover, some media, such the Associated Press, the BBC, Swiss public radio, and The Conversation in Australia, have publicly pledged to move away from giving space to some, and in several cases all, types of climate skeptics or to change the nomenclature to describe them. Other news organizations are following a de facto policy of not giving space to skeptics, even though they might not declare this in public.

\subsection{The increasing influence of public relations on climate journalism}

Generally, scholars have diagnosed a strong and increasing influence of PR on climate journalism. It has been claimed that "one of the more sobering consequences of newsroom restructuring" and downsizing is that PR has attained an "enhanced power [...] to shape the 
news on climate science and policy" and that this "reliance on PR is even more profound in science and environmental reporting than in the newsroom as a whole" (Gibson, 2017, p. 455; Vogler \& Schäfer, 2020). This dependence on PR sources has long been identified in environmental journalism in general, where "around a half of all environmental news stories and approximately $20 \%$ of environmental coverage originate from press releases." However, it is likely that this trend has increased in recent times (Anderson, 2017, p. 472). Due to the effects of the above-mentioned crisis of journalism on journalists' working conditions, almost "half of UK specialists claim that they now have 'less time' to check facts for accuracy" and "only 23 per cent say that 'most of their stories' originated with their own 'active journalistic investigation' [while] 46 per cent say they are more often than not the 'passive recipients' of news story ideas from sources" (Williams, 2015, p. 199).

\subsection{Source relations in the Global North and Global South}

Generally, studies have shown clear cross-country differences, which are particularly pronounced between the Global North and the Global South. This is not only true in relation to the above-mentioned featuring of skeptic sources but also regarding the proportion of foreign, international, and transnational sources in different countries' climate-related news (cf. Nguyen et al., 2020).

Robust evidence shows a strong "domestication" (Eide \& Kunelius, 2010) - that is, a representation of domestic sources - in countries with fossil-heavy national economies (Barkemeyer et al., 2017; Schmidt et al., 2013). An analysis of 15 countries shows that while non-domestic sources appear in the media of "industrial countries" of the West, more such sources appear in "emerging market" countries such as India, that their proportion is highest in "developing nations," and that this holds true for both mentioning and quoting of sources (Schäfer et al., 2018). Other cross-national studies reported similar findings (Eide \& Kunelius, 2010; Nguyen et al., 2020), and numerous national case studies have shown that international sources are more important in countries in the Global South, such as Brazil (Carvalho \& Loose, 2018), China (Anderson, 2017), India (Billett, 2010), Pakistan (Ali, 2010), Peru (Takahashi \& Martinez, 2017), the Philippines (Evans, 2016), and South Africa (Suliman, 2018; Tagbo, 2010). Many of these studies also emphasize the importance of international news agencies as sources for journalists in these countries (e.g., Ali, 2010; Evans, 2016; Orgeret, 2010; Tagbo, 2010; Takahashi \& Martinez, 2017). It seems that in "developing countries climate change is often viewed by editors as an international story and [that] local reporting is not prioritized" (Anderson, 2017, p. 473). This supports findings from "global news flow" and "news geography" research, which has shown that since the 1960s, the news flow between countries has been "unbalanced, with heavy coverage of a few highly developed countries and light coverage of many less-developed ones." (Comfort et al., 2019, p. 5)

\section{CONCLUSION}

The scholarship assembled in this advanced review shows pronounced shifts in climate journalism, that is, in the production of climate-related news. It demonstrates that the organizational embedding of climate journalism is changing, with a decreasing number of specialist reporters and reporters working under more strenuous conditions, in addition to the 
emergence of online-born news media and niche sites that focus on climate-related news. In addition, research indicates considerable differences between countries in the Global North and those in the Global South, which have particularly few specialist reporters, and where journalists work under even more difficult circumstances, and where specific types of online players are emerging with notable climate coverage. Research has also shown that the range of roles available to climate journalists has diversified and that a general shift has occurred from gatekeeping to curating roles, with climate journalists observing the news flow and determining its orientation. The scholarship also indicates that climate journalists' relation to their sources has changed. The range of available sources has diversified, and while elite sources have been, and still are, important, they are no longer restricted chiefly to scientists but rather encompass a broader range of stakeholders. This has been accompanied by a considerable and rising influence of PR on climate journalism.

These changes are in line with changes in climate-related news coverage itself, which is the product of climate journalism. They can partly explain aspects such as the coverage of climate change across beats, its broadening spectrum of frames, and why online-born journalistic players play such an important role in the climate-related discourse of countries such as the US (for an overview, see Painter \& Schäfer, 2018).

But scholarship also documents clear differences between countries. While many of these differences are aligned with the cleavage between the Global South and the Global North, researchers have also demonstrated considerable variation within the Global North, such as the differences between countries with highly commercialized media systems such as the US and countries with stronger public service broadcasting.

In general, many of the aspects of climate journalism described here are notably underresearched. The scholarship on the topic has pronounced holes and biases, and some of the findings presented in this advanced review require substantiation by further research.

First, much of the existing research has focused on climate journalism in commercial legacy media in the US. A relatively significant body of research is also available on the UK and the rest of Europe, but less is known about China, India and other Asian countries, and very little is known about Africa and Latin America (Comfort \& Park, 2018; Schäfer \& Schlichting, 2014).

Second, the amount of research on print media is disproportionate to both its role as a source of climate-related news and its general role in the broader media system. Climate journalism in television, digital-born media, and on online sites, while rising in importance, is often ignored by scholars. This is not only true for the Global North but also for countries such as Brazil and India, where TV is a key source of information about news in general and climate change in particular. In addition, much of the research focuses on national media, whereas local media can play a critical role in providing information to local publics and should be subjected to more scholarly analysis (cf. Howarth \& Anderson, 2019).

Third, the analysis of climate-related news is still largely limited to textual analysis. In online and social media, but also in many legacy media, a turn toward visual journalism has occurred (O'Neill \& Smith, 2014). More analyses of visual and audiovisual forms of climate-related news are needed, especially in light of the impact and success of such news on social media (Painter, 2019). 
Fourth, methodological diversity is lacking in research on climate journalism. Surveys of journalists have dominated the scholarship so far. These are not only time-consuming and expensive but are also reliant on journalists' participation and self-assessment and limited to standardized and not particularly detailed measurements. Qualitative interviews can partly remedy this, but more ethnographic research and participant observation in newsrooms are necessary as it is not dependent on self-assessments. Furthermore, reliable baselines for longitudinal comparisons (e.g., regarding staffing numbers and the development of climate journalism more broadly) do not exist yet, even in the US, which has been the subject of the most research.

Furthermore, due to the rapidly changing media ecosystem, many of the studies aggregated here are already out of date. At the same time, several aspects of these changes have not yet been researched at all. For example, no work has looked at how instantly available audience metrics affect the work of climate journalists. Generally, at a time when, for many legacy and digital-born media, algorithms play a crucial role in determining the selection, presentation, and formats of journalistic products and the successes and failures of their distribution via various platforms, the impact of technological affordances and imperatives on climate journalism is under-explored (cf. Küng, 2016).

In addition, more recent developments have not yet been considered. Since 2017, the New York Times has had a large journalistic team dedicated specifically to climate change. In 2019, media coverage about climate change peaked in volume (Boykoff et al., 2020), and international initiatives (e.g., "Covering Climate Now" which was supported by 400 media worldwide) have tried to boost coverage on climate change. Individual broadcasters, such as the BBC in the UK, NBC in the US, and NRK in Norway, have increased their coverage across different platforms. Debates about the language of coverage, the merits and pitfalls of journalists acting as advocates, and new formats for climate coverage have intensified (Painter and Osaka, 2019). Research on these recent developments is necessary to determine whether they are indicators of sustainable changes in climate journalism that will permanently affect its production, outcomes, and impact or whether they merely represent temporary peaks of societal attention, the likes of which have been observed before, such as around the Fourth Assessment Report of the IPCC or the COPs in Copenhagen and Paris (Painter \& Schäfer, 2018).

Therefore, more analyses of climate journalism - and climate change communication more generally - are needed. These studies should be conceptually and empirically relate to the fundamental changes in the media ecosystem. With some notable exceptions (Brüggemann, 2017; Engesser, 2017; Gibson et al., 2016; Gibson, 2017), research has failed to link these macro changes to the professional practice of climate journalists. More such contextualization - even though it is difficult to establish robust causal links between the two - could provide insights into the complex relationship between macro trends, the organizational meso level, and the micro level of individual journalists (Engesser, 2017; Shoemaker \& Reese, 1995), which would add nuance to the analysis of climate-related news content and audience reception.

\section{Funding Information}


Mike S. Schäfer is indebted to the Reuters Institute for the Study of Journalism at the University of Oxford for a Research Fellowship during which parts of this review were written.

\section{Acknowledgments}

The authors thank Aruna Chandrasekhar, Carlos Fioravanti, David Holmes, Libby Lester, Wiebke Loosen, and Saffron O'Neill for helpful comments and inputs for this review, as well as Lukas Tribelhorn for assistance in producing the visual abstract.

\section{Further Reading}

Anderson, A. (2015). News organization(s) and the production of environmental news. In A. Hansen and R. Cox (Eds.), The Routledge handbook of environment and communication (pp. 176-185). Oxon: Routledge.

Brüggemann, M. (2017). Shifting roles of science journalists covering climate change. In M.C. Nisbet, S. S. Ho, E. Markowitz, S. J. O'Neill, M. S. Schäfer, \& J. Thaker (Eds.), Oxford research encyclopedia on climate change communication.

Friedman, S. M. (2015) The changing face of environmental journalism in the United States. In A. Hansen \& R. Cox (Eds.), The Routledge handbook of environment and communication (pp. 144-157). Oxon: Routledge.

Gibson, T. (2017). Economic, technological, and organizational factors influencing news coverage of climate change. In M. C. Nisbet, S. S. Ho, E. Markowitz, S. J. O'Neill, M. S. Schäfer, \& J. Thaker (Eds.), Oxford research encyclopedia on climate change communication. New York: Oxford University Press.

Williams, A. (2015). Environmental news journalism, public relations and news sources. In A. Hansen \& R. Cox (Eds.), The Routledge handbook of environment and communication (pp. 197-206). Oxon: Routledge.

\section{REFERENCES}

Ali, Z. S. (2010). Pakistan: Vulnerability, needs and neglect. In E. Eide, R. Kunelius, \& V. Kumpu (Eds.), Global climate - Local journalisms (pp. 261-274). Bochum: Projekt Verlag.

Anderson, A. (2015). News organization(s) and the production of environmental news. In A. Hansen \& R. Cox (Eds.), The Routledge handbook of environment and communication: (pp. 176-185). Oxon: Routledge.

Anderson, A. (2017). Source influence on journalistic decisions and news coverage of climate change. Oxford Research Encyclopedia of Climate Science.

Aneez, Z., Neyazi, A., Kalogeropoulos, A., et al. (2019). India Digital News Report.

Antwi, A. (2018). Media representations of climate change: A meta-analysis of the research field on Africa (Unpublished master's essay). Oxford University, Oxford.

Appiah, B., Gastel, B., Burdine, J. N., et al. (2015). Science reporting in Accra, Ghana: Sources, barriers and motivational factors. Public Understanding of Science, 24(1), 23-37.

Atton, C. (2009). Alternative and citizen journalism. The handbook of journalism studies (pp. 265-278).

Bacon, W., \& Nash, C. (2012). Playing the media game: The relative (in)visibility of coal industry interests in media reporting of coal as a climate change issue in Australia. Journalism Studies, 13(2), 243-258. 
Barkemeyer, R., Figge, F., Hoepner, A., et al. (2017). Media coverage of climate change: An international comparison. Environment and Planning C: Politics and Space: $0263774 X 16680818$.

Bauer, M., \& Gregory, J. (2007). From journalism to corporate communication in post-war Britain. In M. Bauer \& M. Bucchi (Eds.), Science, journalism and society: Science communication between news and public relations (pp. 33-52). London: Routledge.

Bauer, M., Howard, S., Romo, R., et al. (2013a). Global science journalism report: Working conditions \& practices, professional ethos and future expectations. London: London School of Economics and Political Science.

Bauer, M.W., Howard, S., Ramos, R., et al. (2013b). Global science journalism report: Working conditions \& practices, professional ethos and future expectations. Science and Development Network.

BBC World Service Trust. (2009). Least responsible, most affected, least informed: Public understanding of climate change in Africa. London: BBC.

Becker, L. B., \& Vlad, T. (2009). News organizations and routines. In K. Wahl-Joergensen \& T. Hanitzsch (Eds.), The handbook of journalism studies (pp. 79-92) London: Routledge.

Billett, S. (2010). Dividing climate change: global warming in the Indian mass media. Climatic Change, 99(1), 1-16.

Boykoff, M., Aoyagi, M., Benham, A., et al. (2020) World Newspaper Coverage of Climate Change or Global Warming, 2004-2019. Retrieved from http://sciencepolicy.colorado.edu/icecaps/research/media_coverage/world/index.html

Boykoff, M., \& Farrell, J. (2019). Climate change countermovement organizations and media attention in the United States. In N. Almiron \& J. Xifra (Eds.), Climate change denial and public relations: Strategic communication and interest groups in climate inaction (pp. 121139) London: Routledge.

Boykoff, M. T. (2011). Who speaks for the climate? Making sense of media reporting on climate change. Cambridge: Cambridge University Press.

Boykoff, M. T., \& Boykoff, J. M. (2004). Balance as bias: Global warming and the US prestige press. Global Environmental Change, 14, 125-136.

Boykoff, M. T., \& Boykoff, J. M. (2007). Climate change and journalistic norms: A case-study of US mass-media coverage. Geoforum, 38(6), 1190-1204.

Boykoff, M. T., \& Yulsman, T. (2013). Political economy, media, and climate change: Sinews of modern life. Wiley Interdisciplinary Reviews: Climate Change, 4(5), 359-371.

Brainard, C. (2015). The changing ecology of news and news organizations: Implications for environmental news. In A. Hansen \& R. Cox (Eds.), The Routledge handbook of environment and communication (168-175). Oxon: Routledge.

Brüggemann, M. (2017). Shifting roles of science journalists covering climate change. Oxford Research Encyclopedia of Climate Science.

Brüggemann, M., \& Engesser, S. (2014). Between consensus and denial: Climate journalists as interpretive community. Science Communication, 36(4), 399-427.

Brüggemann, M., \& Engesser, S. (2017). Beyond false balance: How interpretive journalism shapes media coverage of climate change. Global Environmental Change, 42, 58-67.

Bubela, T., Nisbet, M. C., Borchelt, R., et al. (2009). Science communication reconsidered. Nat Biotech, 27(6), 514-518. 
Burgh, H. D., \& Zeng, R. (2012). Environment correspondents in China in their own words: Their perceptions of their role and the possible consequences of their journalism. Journalism: Theory, Practice \& Criticism, 13(8), 1004-1023.

Callison, C., \& Tindall, D. B. (2017). Climate change communication in Canada. Oxford Research Encyclopedia of Climate Science.

Carpenter, C. (2001). Businesses, green groups and the media: The role of non-governmental organizations in the climate change debate. International Affairs, 77(2), 313.

Carvalho, A. (2010). Media(ted)discourses and climate change: A focus on political subjectivity and (dis)engagement. WIREs Climate Change, 1(2), 172-179.

Carvalho, A. \& Loose, E. B. (2018). Climate change in the Brazilian media. In B. Brevini \& J. Lewis (Eds.), Climate change in the media (pp. 79-94). New York: Peter Lang.

Chadha, K. (2017). The Indian news media industry: Structural trends and journalistic implications. Global media and Communication, 13(2), 139-156.

Comfort, S. E., \& Park, Y. E. (2018). On the field of environmental communication: A systematic review of the peer-reviewed literature. Environmental Communication-a Journal of Nature and Culture, 12(7), 862-875.

Comfort, S. E., Tandoc, E., \& Gruszczynski, M. (2019). Who is heard in climate change journalism? Sourcing patterns in climate change news in China, India, Singapore, and Thailand. Climatic Change, 1-17.

Dayrell, C., \& Urry, J. (2015). Mediating climate politics: The surprising case of Brazil. European Journal of Social Theory, 18(3), 257-273.

Dryzek, J. S., Norgaard, R. B., \& Schlosberg, D. (Eds.). (2011). The Oxford handbook of climate change and society. London: Oxford University Press.

Dunwoody, S. (2014). Science journalism. Routledge Handbook of Public Communication of Science and Technology: 27.

Eide, E., \& Kunelius, R. (2010). Domesticating global moments. A transnational study on the coverage of the Bali and Copenhagen Climate Summits. In E. Eide, R. Kunelius, \& V. Kumpu $\mathrm{V}$ (Eds), Global climate - Local journalisms (pp. 11-50). Bochum: Projekt Verlag.

Engesser, S. (2017). Impact of journalistic background, professional norms, and culture on climate change coverage. Oxford Research Encyclopedia of Climate Science.

Engesser, S., \& Brüggemann, M. (2016). Mapping the minds of the mediators: The cognitive frames of climate journalists from five countries. Public Understanding of Science, 25(7), 825-841.

Eskjær, M. F. (2017). Climate change communication in Middle East and Arab countries. Oxford Research Encyclopedia of Climate Science.

Evans, S. (2016). Journalistic norms, cultural values, and coverage of climate change in the Philippines. Environmental Communication, 10(4), 492-507.

Fahy, D. (2017). Objectivity, false balance, and advocacy in news coverage of climate change. Oxford research encyclopedia on climate change communication.

Fahy, D. (2018). Objectivity as trained judgment: How environmental reporters pioneered journalism for a "post-truth" era. Environmental Communication - A Journal of Nature and Culture, 12(7), 855-861.

Fahy, D., \& Nisbet, M. C. (2011). The science journalist online: Shifting roles and emerging practices. Journalism, 12(7), 778-793. 
Finlay, A. (2012). Systemic challenges to reporting complexity in journalism: HIV/Aids and climate change in Africa. Ecquid Novi: African Journalism Studies, 33(1), 15-25.

Forde, S. (2017). Alternative approaches to environment coverage in the digital era. Journalism and Climate Crisis: Public Engagement, Media Alternatives, 167.

Friedman, S. M. (2015). The changing face of environmental journalism in the United States. In A. Hansen \& R. Cox (Eds.), The Routledge Handbook of Environment and Communication (pp. 144-157). Oxon: Routledge.

Geall, S., \& Hilton, I. (2013). China and the environment: The green revolution. London: Zed Books.

Giannoulis, C., Botetzagias, I., \& Skanavis, C. (2010). Newspaper reporters' priorities and beliefs about environmental journalism: An application of Q-methodology. Science Communication, 32(4), 425-466.

Gibson, T. (2017). Economic, technological, and organizational factors influencing news coverage of climate change. Oxford research encyclopedia on climate change communication.

Gibson, T. A., Craig, R. T., Harper, A. C., et al. (2016). Covering global warming in dubious times: Environmental reporters in the new media ecosystem. Journalism: Theory, Practice \& Criticism, 17(4), 417-434.

Guenther, L., \& Joubert, M. (2017). Science communication as a field of research: Identifying trends, challenges and gaps by analysing research papers. Journal of Science Communication, 16(2), 1-19.

Hallin, D. C., \& Mancini, P. (2004). Comparing media systems. Three models of media and politics. New York: Cambridge University Press.

Hanitzsch, T. (2011). Populist disseminators, detached watchdogs, critical change agents and opportunist facilitators: Professional milieus, the journalistic field and autonomy in 18 countries. International Communication Gazette, 73(6), 477-494.

Hansen, A. (2010). Environment, media and communication. Routledge.

Hansen, A., \& Cox, R. (2015a). Introduction: Environment and communication. In A. Hansen \& R. Cox (Eds.), The Routledge handbook of environment and communication (pp. 1-10). Oxon: Routledge.

Hansen, A., \& Cox, R. (Eds.). (2015b). The Routledge handbook of environment and communication. Oxon: Routledge.

Hellmueller, L., Cheema, S. E., \& Zhang, X. (2017). The networks of global journalism. Journalism Studies, 18(1), 45-64.

Hoeppner, C. (2010). Rereading public opinion polls on climate change in the UK press. International Journal of Communication, 4, 977-1005.

Holmes, D., \& Richardson, L. (Eds.). (2020). Research handbook in communicating climate change. Edward Elgar.

Horta, A., \& Carvalho, A. (2017). Climate change communication in Portugal. Oxford University Press.

Howarth, C., \& Anderson, A. (2019). Increasing local salience of climate change: The un-tapped impact of the media-science interface. Environmental Communication, 13(6), 713-722.

Internet World Stats. (2019). Internet World Stats. Usage and Population Statistics. Retrieved from https://www.internetworldstats.com/stats.htm 
Keller, T. R., Hase, V., Thaker, J., et al. (2019). News media coverage of climate change in India 1997-2016: Using automated content analysis to assess themes and topics.

Kleis Nielsen, R., \& Ganter, S. A. (2018). Dealing with digital intermediaries: A case study of the relations between publishers and platforms. New Media \& Society, 20(4), 1600-1617.

Kristiansen, S., Schäfer, M. S., \& Lorencez, S. (2016). Science journalists in Switzerland: Results from a survey on professional goals, working conditions, and current changes. Studies in Communication Sciences, 16(2), 132-140.

Küng, L. (2016). Innovators in digital news. Oxford: Tauris.

Leal Filho, W., Manolas, E., Azul, A. M., et al. (Eds.). (2018). Handbook of climate change communication. Springer.

Lester, L. (2013). On flak, balance and activism: The ups and downs of environmental journalism.

Li, J., \& Dan, L. (2017) Climate change communication in China. Oxford Research Encyclopedia of Climate Science.

Lück, J., Wozniak, A., \& Wessler, H. (2016) Networks of coproduction: How journalists and environmental NGOs create common interpretations of the UN climate change conferences. The International Journal of Press/Politics, 21(1), 25-47.

McNutt, K. (2008). Policy on the web: The climate change virtual policy network. Canadian Political Science Review, 2(1), 1-151.

Mellado, C., Hellmueller, L., \& Donsbach, W. (2017). Journalistic role performance: Concepts, contexts, and methods. New York: Routledge.

Mercado-Sáez, M. T., \& Galarza, C. (2017). Climate change communication in Argentina. Oxford Research Encyclopedia of Climate Science.

Metag, J., Füchslin, T., \& Schäfer, M. S. (2017). Global warming's five Germanys: A typology of Germans' views on climate change and patterns of media use and information. Public Understanding of Science, 26(4), 434-451.

Mittal, R. (2012). Climate change coverage in Indian print media: A discourse analysis.

Moser, S. C. (2010). Communicating climate change: History, challenges, process and future directions. WIREs Climate Change, 1, 31-53.

Murcott, T. H. L., \& Williams, A. (2013). The challenges for science journalism in the UK. Progress in Physical Geography, 37(2), 152-160.

Nassanga, G., Eide, E., Hahn, O., et al. (2017). Climate change and development journalism in the Global South. In R. Kunelius, E. Eide, M. Tegelberg, \& D. Yagodin (Eds.), Media and Global Climate Knowledge (pp. 213-233). Springer.

Newman, N. (Ed.). (2016). Reuters institute digital news report 2016. Oxford: Reuters Institute for the Study of Journalism.

Newman, N. (Ed.). (2020). Digital news report 2020. Oxford: Reuters Institute for the Study of Journalism.

Newman, N., Fletcher, R., Kalogeropoulos, A., et al. (2019). Reuters institute digital news report 2019. Oxford: Reuters Institute for the Study of Journalism.

Newman, T. P., Nisbet, E. C., \& Nisbet, M. C. (2018). Climate change, cultural cognition, and media effects: Worldviews drive news selectivity, biased processing, and polarized attitudes. Public Understanding of Science, 27(8), 985-1002. 
Nguyen, A., Tran, M., \& Da, N. (2020). Science journalism for development in the Global South: A systematic literature review of issues and challenges. Public Understanding of Science.

Nicholls, T., Shabbir, N., Graves, L., et al. (2018). Coming of age: Developments in digital-born news media in Europe.

Nicholls, T., Shabbir, N., \& Nielsen, R. (2016). Digital-born news media in Europe.

Nielsen, R., \& Sen, A. (2016). Digital journalism start-ups in India. 19073842.

Nielsen, R. K. (2016). News media, search engines and social networking sites as varieties of online gatekeepers. In Rethinking journalism again (pp. 93-108). Routledge.

Nisbet, M. C. (2019). Sciences, Publics, Politics MINDFULNESS INC. NATL ACAD SCIENCES 2101 CONSTITUTION AVE NW, WASHINGTON, DC 20418 USA.

Nisbet, M. C., Ho, S. S., Markowitz, E., et al. (Eds.). (2017). Oxford Research Encyclopedia on Climate Change Communication.

Nisbet, M. C., \& Newman, T. P. (2015). Framing, the Media, and Environmental Communication. In A. Hansen and R. Cox (Eds.), The Routledge handbook of environment and communication (pp. 325-338). Oxon: Routledge.

Olausson, U. (2009). Global warming-global responsibility? Media frames of collective action and scientific certainty. Public Understanding of Science, 18(4), 421-436.

O'Neill, S. J., \& Smith, N. (2014). Climate change and visual imagery. Wiley Interdisciplinary Reviews: Climate Change, 5(1), 73-87.

Orgeret, K. S. (2010). South Africa: A balancing act in a country of (at least) two nations. In E. Eide, R. Kunelius, \& V. Kumpu (Eds.), Global climate - Local journalisms (pp. 291-308). Bochum: Projekt Verlag.

Painter, J. (2011). Poles apart: The international reporting on climate scepticism. London: Reuters Institute for the Study of Journalism.

Painter, J. (2013). Climate change in the media: Reporting risk and uncertainty. Oxford: Tauris.

Painter, J. (2016) Journalistic depictions of uncertainty about climate change. Oxford Research Encyclopedia of Climate Science.

Painter, J. (2017). Disaster, risk or opportunity? A ten-country comparison of themes in coverage of the IPCC AR5. In R. Kunelius, E. Eide, M. Tegelberg, \& D. Yagodin (Eds.), Media and Global Climate Knowledge (pp. 109-128). Springer.

Painter, J. (2019). Climate change journalism: Time to adapt. Environmental Communication A Journal of Nature and Culture, 13(3), 424-429.

Painter, J., \& Ashe, T. (2012). Cross-national comparison of the presence of climate scepticism in the print media in six countries, 2007-10. Environmental Research Letters, 7(4), 1-8.

Painter, J., Erviti, M. C., Fletcher, R., et al. (2016) Something old, something new. Digital media and the coverage of climate change. Oxford: Reuters Institute for the Study of Journalism.

Painter, J., \& Gavin, N. T. (2016) Climate skepticism in British newspapers, 2007-2011. Environmental Communication - A Journal of Nature and Culture, 10(4), 432-452.

Painter, J., Kristiansen, S., \& Schäfer, M. S. (2018). How 'digital-born' media cover climate change in comparison to legacy media: A case study of the COP 21 summit in Paris. Global Environmental Change, 48, 1-10.

Painter, J., \& Osaka, S. (2019). Five Tips for Better Coverage of the Climate Crisis. Retrieved from niemanreports.org/articles/five-tips-for-better-coverage-of-the-climate-crisis/. 
Painter, J., \& Schäfer, M. S. (2018) Global similarities and persistent differences: A survey of comparative studies on climate change communication. In B. Brevini \& J. Lewis (Eds.), Climate Change in the Media. New York: Peter Lang.

Pearce, W., Holmberg, K., Hellsten, I., et al. (2014). Climate change on Twitter: Topics, communities and conversations about the 2013 IPCC Working Group 1 report. Plos One, 9(4), e94785.

Pearce, W., Niederer, S., Özkula, S. M., et al. (2019). The social media life of climate change: Platforms, publics, and future imaginaries. Wiley Interdisciplinary Reviews - Climate Change, 10(2), e569.

Peters, H. P., \& Heinrichs, H. (2005). Öffentliche Kommunikation über Klimawandel und Sturmflutrisiken. Bedeutungskonstruktion durch Experten, Journalisten und Bürger. Jülich: Forschungszentrum Jülich.

Rauchfleisch, A., \& Schäfer, M. S. (2015). Multiple public spheres of Weibo: A typology of forms and potentials of online public spheres in China. Information, Communication \& Society, 18(2), 139-155.

Russell, A. (2016). Networked journalism. In T. Witschge, C. W. Anderson, D. Domingo, \& T. Hanitzsch (Eds.), The Sage handbook of digital journalism (pp. 149-165). London: Sage.

Sachsman, D. B., Simon, J., \& Valenti, J. M. (2010). Environment reporters in the 21st century. New Brunswick: Transaction.

Salvesen, I. (2018). Should journalists campaign on climate change? Oxford: Reuters Institute for the Study of Journalism.

Schäfer, M. S. (2011). Sources, characteristics and effects of mass media communication on science: A review of the literature, current trends and areas for future research. Sociology Compass, 5(6), 399-412.

Schäfer, M. S. (2012a). Online communication on climate change and climate politics: A literature review. Wiley Interdisciplinary Reviews - Climate Change, 3(6), 527-543.

Schäfer, M. S. (2012b). Taking stock: A meta-analysis of studies on the media's coverage of science. Public Understanding of Science, 21(6), 650-663.

Schäfer, M. S. (2017). How changing media structures are affecting science news coverage. In K. H. Jamieson, D. M. Kahan, \& Scheufele, D. (Eds.), The Oxford handbook on the science of science communication (pp. 51-59). Oxford University Press.

Schäfer, M. S., Ivanova, A., \& Schmidt, A. (2014). What drives media attention for climate change? Explaining issue attention in Australian, German and Indian print media from 1996 to 2010. International Communication Gazette, 76(2), 152-176.

Schäfer, M. S., Post, S., Schwab, R., et al. (2018). Transnationalisierte Öffentlichkeit und Klimapolitik. Publizistik. doi: 10.1007/s11616-018-0420-6.

Schäfer, M. S., \& Schlichting, I. (2014). Media representations of climate change: A metaanalysis of the research field. Environmental Communication: A Journal of Nature and Culture, 8(2), 142-160.

Scheufele, D. A. (2013). Communicating science in social settings. Proceedings of the National Academy of Sciences. doi: 10.1073/pnas.1213275110.

Schlichting, I. (2013). Strategic framing of climate change by industry actors: A meta-analysis. Environmental Communication: A Journal of Nature and Culture, 7(4), 493-511. 
Schmidt, A., Ivanova, A., \& Schäfer M. S. (2013). Media attention for climate change around the world: A comparative analysis of newspaper coverage in 27 countries. Global Environmental Change, Online First.

Shanahan, M. (2009). Time to adapt? Media coverage of climate change in nonidustrialised countries. In T. Boyce \& J. Lewis (Eds.), Climate change and the media (pp. 145-157). New York: Peter Lang.

Shoemaker, P. J., \& Reese, S. D. (1995). Mediating the message: Theories of Influence on mass media content. New York: Longman.

Shoemaker, P. J., \& Reese, S. D. (2013). Mediating the message in the 21st century: A media sociology perspective. Routledge.

Suliman, L. (2018). A review of environmental news reporting in South Africa case studies on climate change and energy fracking and acid mine drainage.

Tagbo, E. (2010) Media coverage of climate change in Africa: A case study of Nigeria and South Africa. Oxford: Reuters Institute for the Study of Journalism.

Takahashi, B. (2011). Framing and sources: A study of mass media coverage of climate change in Peru during the V ALCUE. Public Understanding of Science, 20(4), 543-557.

Takahashi, B., \& Martinez, A. (2017). Climate change communication in Peru 1.

Takahashi, B., \& Tandoc Jr., E. C. (2016). Media sources, credibility, and perceptions of science: Learning about how people learn about science. Public Understanding of Science, 25(6), 674-690.

Tandoc, E. C., \& Eng, N. (2017). Climate change communication on Facebook, Twitter, Sina Weibo, and other social media platforms. Oxford Research Encyclopedia of Climate Science.

Tandoc, Jr., E. C., \& Takahashi, B. (2014). Playing a crusader role or just playing by the rules? Role conceptions and role inconsistencies among environmental journalists. Journalism: Theory, Practice \& Criticism, 15(7), 889-907.

Vogler, D., \& Schäfer, M. S. (2020) Growing influence of university PR on science news coverage? A longitudinal automated content analysis of university media releases and newspaper coverage in Switzerland, 2003-2017. International Journal of Communication.

WAN-IFRA (2017) World Press Trends 2017. Frankfurt: WAN-IFRA.

Wihbey, J., Ward, B. (2016). Communicating about climate change with journalists and media producers. Oxford Research Encyclopedia of Climate Science.

Williams, A. (2015). Environmental news journalism, public relations and news sources. In A. Hansen \& R. Cox (Eds.), The Routledge handbook of environment and communication (pp. 197-206). Oxon: Routledge.

Williams, A., \& Clifford, S. (2010). Mapping the field: A political economic account of specialist science news journalism in the UK national media. Cardiff: Cardiff University.

Yang, G. (2010). Brokering environment and health in China: Issue entrepreneurs of the public sphere. Journal of Contemporary China, 19(63), 101-118.

Zelizer, B. (2009). Journalism and the academy. In The handbook of journalism studies (pp. 4961). Routledge.

Zelizer, B. (2017). What journalism could be. John Wiley \& Sons. 